\title{
Tumour biomarker expression relative to age and molecular subtypes of invasive breast cancer
}

\author{
DH Morrison', D Rahardja ${ }^{2}$, E King', Y Peng' and VR Sarode*,I \\ 'Department of Pathology, The University of Texas Southwestern Medical Center at Dallas, 5323 Harry Hines Building, Dallas, TX 75390-9073, USA; \\ ${ }^{2}$ Department of Biostatistics, The University of Texas Southwestern Medical Center at Dallas, 5323 Harry Hines Building, Dallas, TX 75390-9073, USA
}

BACKGROUND: Quantitative differences in biomarker expression relative to age and molecular subtypes have not been well documented in invasive breast cancer (IBCA).

METHODS: Oestrogen receptor (ER), progesterone receptor (PR), HER2, ki67, p53 and DNA ploidy was performed by image analysis in 162 consecutive IBCAs in women ( $\leqslant 40$ years) and compared with women $\geqslant 50$ years ( 100 cases). Molecular subtypes were defined by immunohistochemistry $(\mathrm{IHC})$.

RESULTS: Among young women, tumours were frequently ER negative $(P=0.0 \mathrm{I})$ with lower $\mathrm{ER}(P<0.00)$, $\mathrm{PR}(P=0.03)$, higher ki67 index $(\mathrm{KI})(P=0.0 \mathrm{I})$ and p53 $(P=0.00)$ compared with older women. Triple negative was more frequent among young women with frequent lymph node involvement compared with older women. Luminal B among young vs old women showed lower ER (67\% vs $88 \%), P R(32 \%$ vs 52\%), higher KI (48\% vs 34\%) and p53 (I $9 \%$ vs 7\%). Linear regression model showed increasing $\mathrm{KI}(\mathrm{P}<0.000 \mathrm{I})$ and p53 $(P=0.0003)$ according to the molecular subtypes. Survival difference among subtypes was demonstrated by multivariate analysis $(P=0.0092)$ after adjusting for age, race, tumour size, grade and stage.

CONCLUSION: We demonstrated significant differences in biomarker expression relative to age and molecular subtypes. Molecular subtype defined by $\mathrm{HC}$ was an independent prognostic factor.

British Journal of Cancer (2012) I 07, 382-387. doi:I0.1038/bjc.2012.219 www.bjcancer.com

Published online 19 June 2012

(C) 2012 Cancer Research UK

Keywords: breast biomarkers; molecular subtypes; young age

Breast cancer among young women $(<40$ years) is a rare disease associated with poor prognosis (Anders et al, 2009). Factors such as race, advanced stage, large tumour size and hormone receptor (HR)-negative status have been shown to contribute to poor prognosis in this age group (Bonnier et al, 1995; Walker et al, 1996; Shavers et al, 2003; Carey et al, 2006; Anders et al, 2009). Recently, gene expression analysis has identified molecular subtypes of invasive breast cancer (IBCA) with distinct biological behaviour and prognosis (Sorlie et al, 2001; Sotriou et al, 2003). Routine immunohistochemistry (IHC) has been used as a substitute for gene expression with fairly good correlation (Bhargava et al, 2009; Cheang et al, 2009; Voduc et al, 2010). It has been suggested that molecular subtypes of IBCA among young women may be different from those among older women (Carey et al, 2006; ihemelangu et al, 2007; Lin et al, 2009). Tumour proliferation and p53 overexpression have important roles in IBCA prognosis (Chae et al, 2009; Yerushalmi et al, 2010), however, their relationship to age and molecular subtypes has not been well elucidated. The aims of this study were to determine if there are differences in biomarker expression (oestrogen receptor (ER), progesterone receptor (PR), human epidermal receptor 2 (HER2), Ki67 and $\mathrm{p} 53)$ and DNA ploidy relative to age $(\leqslant 40 v s \geqslant 50$ years $)$

\footnotetext{
* Correspondence: Dr VR Sarode;

E-mail: venetia.sarode@utsouthwestern.edu

Received 6 February 2012; revised 20 April 2012; accepted 24 April 2012; published online 19 June 2012
}

and molecular subtypes of IBCA using digital image analysis. We also evaluated the relationship of the subtypes to disease outcome.

\section{MATERIALS AND METHODS}

We identified 162 consecutive cases of IBCAs among women $\leqslant 40$ years. In all, 158 cases had information on tumour biomarkers and DNA ploidy performed between 1999 and 2009 at the UT Southwestern Medical Centre, Dallas. In four cases biomarker were performed at other institutions and not quantified by image analysis and were excluded. A comparison was made with IBCA occurring among women $\geqslant 50$ years during the same period. There were 100 cases in this group, of which one case was excluded due to lack of biomarker information. Clinical information, including race, age at diagnosis, clinical stage, pre-surgical chemotherapy, type of surgery, post-surgical therapy and follow-up information, was obtained from the electronic medical records after Institutional Review Board approval. Tumour size, nodal stage, histological subtypes, tumour grade and results of biomarkers (ER, PR, HER2, Ki67 and P53) and DNA ploidy were extracted from the pathology database. These were performed prospectively on excision specimens at the time of diagnosis, as part of the clinical work-up. Histological classification was done according to the World Health Organisation. Tumour was graded according to the modified Nottingham grading system. 


\section{Immunohistochemistry and quantitation of biomarker expression}

Slides were stained on an automated immunostainer (Dako autostainer, Carpintaria, CA, USA) using ER (clone1D5, 1:800), PR (PgR 636, 1: 1000) and Ki67 (MIB-1, 1:300), HER2/neu (1:600) and p53 (DO-7, 1:220) (Dako autostainer). Scoring and quantification was performed using the computerised Automated Cellular Imaging System (ACIS, Clarient, Inc., San Juan Capistrano, CA, USA). This consists of an automated robotic bright-field microscope module, a computer and a Windows NT-based software interface. Sub-regions were selected from the digital images of the IHC-stained slides for analysis. Positive staining in $\geqslant 5 \%$ of the tumour cells for ER and PR in 10 selected sub-regions of the tumour was the cut-off for positive result. The results were reported as percentage of positive staining nuclei and intensity was graded from $1+$ to $3+$.

Computer-generated results were reviewed by pathologists with experience in image analysis to confirm that the area of invasive tumour was analysed. The computer scores were taken as the final scores. To assess HER2 overexpression, ACIS provided an average score for five selected sub-regions of the tumour with the highest cytoplasmic membrane-staining intensity for HER2. Tumours with $>10 \%$ cells with an average score $\geqslant 2.0(3+)$ were reported as positive overexpression, scores between 1.4 and 1.9 as borderline $(2+)$ and $<1.4$ as negative $(0$ and $1+)$. All the positive and borderline results were confirmed by fluorescent in situ hybridisation (FISH) using the FDA-approved PathVysion kit (Abbott-Vysis Lab, Abbott Park, IL, USA) according to the manufacturer's protocol. A ratio of the number of HER2 gene signals to chromosome $17>2.0$ was reported as amplified using the FDA criteria. The P53 expression in $\geqslant 10 \%$ of the tumour cells was considered as overexpression.

\section{DNA ploidy analysis}

DNA analysis was performed by image analysis using Feulgenstained paraffin sections from the same tumour block. DNA ploidy was analysed using the Autocyte Pathology Workstation (Tripath, Burlington, NC, USA). Briefly, a total of 200-300 nuclei were collected and DNA index was obtained by measuring the optical density of tumour cells in comparison with those of stromal cells in the section, using the latter as the diploid reference (value of 1.0). Tumours were classified as diploid or aneuploid/multiploid.

\section{Molecular classification of IBCA by IHC}

The Ki67 index (KI) was used to define luminal A and B tumours according to Cheang et al (2009). Tumours were classified as luminal A $(\mathrm{ER}+/ \mathrm{PR} \pm / \mathrm{HER} 2-$, Ki67 $\leqslant 14 \%)$; luminal B $(\mathrm{ER}+I$ $\mathrm{PR} \pm /$ HER2 - , Ki67 > 14\%), luminal-Her2 (ER + /PR $\pm /$ HER2 + $++)$; HER $2+(\mathrm{ER}-/ \mathrm{PR}-/ \mathrm{HER} 2+++)$ and triple negative $(\mathrm{ER}-/ \mathrm{PR}-/$ HER2 -$)$.

\section{Statistical methods}

The Fisher's exact test was used to analyse categorical variables and the two-sample $t$-test for continuous variables. Multivariate analysis was performed using logistic regression model and the general linear model to analyse categorical and continuous variables, respectively, after adjusting for age, race, tumour grade, ploidy, tumour size and $\mathrm{T}$ and $\mathrm{N}$ stage. Univariate analyses were performed for each of the IBCA subtypes to compare tumour size, grade and lymph node status and biomarker expression in the two groups. Linear regression models and F-tests were used to determine the relationship of ki67 and p53 expression and molecular subtypes.
Disease-free survival (DFS) was defined as time from diagnosis to recurrence or death, whichever occurred first, and was censored at the date of last follow-up for those alive without recurrence. Survival curves were produced using the Kaplan-Meier method and the log-rank test was used to compare survival curves between the two age groups and molecular subtypes. Cox regression analysis was performed to determine if molecular subtypes retained significance after adjusting for $\mathrm{T}$ and $\mathrm{N}$ stages, race, tumour size, grade and ploidy.

Two-sided $P$-values $<0.05$ were considered significant. All analyses were conducted using SAS 9.2 software package (SAS Institute Inc., Cary, NC, USA).

\section{RESULTS}

A comparison of clinico-pathological variables is shown in Table 1. The mean age at diagnosis was 34.6 years in young and 61.8 years in old women. Young women frequently belonged to minority race. Tumours among young women were significantly larger, of higher grade and with advanced $\mathrm{T}$ and $\mathrm{N}$ stages compared with older women. There was no significant difference in DNA ploidy in the two groups. Young women were more likely to receive pre-surgical chemotherapy, modified radical and bilateral mastectomies and frequent post-surgical chemotherapy and radiation than older women.

A comparison of biomarkers expression is shown in Table 2. Among young women, tumours were frequently ER negative with lower ER levels compared with older women. There was a trend towards PR negativity and lower PR levels among young women. There was no difference in rates of HER2 overexpression between the two groups. The KI, frequency of p53 overexpression and levels of p53 was significantly higher among young $v s$ older women. Of the molecular subtypes, triple negative and HER2 subtypes were more frequent among young compared with older women $(P=0.000$ and 0.015 , respectively).

By multivariate analysis, the mean $\mathrm{ER}(P=0.040)$ and $\mathrm{PR}$ $(P=0.031)$ levels, tumour grade $(P<0.0001)$ and DNA ploidy $(P=0.0021)$ were independently associated with age, after controlling for race, $\mathrm{T}$ and $\mathrm{N}$ stages, tumour size and grade, whereas the KI was not significant $(P=0.469)$ and p53 was mildly significant $(P=0.064)$. After adjusting for molecular subtypes, the levels of ER $(P=0.009)$ and p53 $(P=0.027)$ were independently associated with age but PR $(0.872)$ and KI $(P=0.246)$ were not. Tumour size $(P=0.048)$ and molecular subtypes $(P=0.049)$ were independently associated with age.

Table 3 shows the comparison of tumour size, grade and lymph node status and biomarker expression for each of the molecular subtypes according to age groups. In luminal A tumours, the ER level was lower among young compared with older women. Among young women with luminal B subtypes, the ER and PR values were significantly lower with higher KI and p53 compared with those among older women.

Luminal B subtype among young women was predominantly high grade, 28 out of $43(65.1 \%)$ vs 9 out of 29 (31.0\%) among older women $(P=0.007)$. Similarly, triple-negative subtype among young women was predominantly high grade, 54 out of 57 $(94.7 \%)$ vs 17 out of $25(68 \%)$ in older women $(P=0.002)$, and was frequently associated with positive lymph nodes, 40 out of 54 $(74.1 \%)$ vs 13 out of $25(52.0 \%)$ compared with the older group $(P=0.072)$.

Linear regression model showed a positive trend toward increasing KI with molecular subtypes in both age groups $(P<0.0001)$, Figure 1. Similar trend was noted for p53 levels in young $(P<0.0001)$ and old women $(P=0.0003)$, Figure 2 .

\section{Survival analysis}

The median DFS was 84 months (95\% CI: 84, NA) for old and 107 months (95\% CI: 60, 144) for young women. Among young 
Table I Comparison of clinico-pathological characteristics in young vs old women

\begin{tabular}{|c|c|c|c|}
\hline Variables & $\leqslant 40$ years & $\geqslant 50$ years & $P$-value ${ }^{a}$ \\
\hline Age (Mean) & 34.6 & 61.8 & $<0.00$ \\
\hline $\begin{array}{l}\text { Race } \\
\text { Caucasian } \\
\text { African American } \\
\text { Hispanic } \\
\text { Other }\end{array}$ & $\begin{array}{l}162(\%) \\
32(19.8) \\
54(33.3) \\
69(42.6) \\
7(4.32)\end{array}$ & $\begin{array}{l}100(\%) \\
46(46) \\
36(36) \\
16(16) \\
2(2)\end{array}$ & $<0.00$ \\
\hline $\begin{array}{c}\text { Grade } \\
1 \\
2 \\
3\end{array}$ & $\begin{aligned} & 153 \\
9 & (5.9) \\
31 & (20.2) \\
113 & (73.9)\end{aligned}$ & $\begin{array}{c}96 \\
11(11.4) \\
47(49.0) \\
38(39.6)\end{array}$ & $<0.00$ \\
\hline $\begin{array}{l}\text { DNA ploidy } \\
\text { Aneuploid } \\
\text { Diploid }\end{array}$ & $\begin{array}{c}150 \\
112(74.7) \\
38(25.3)\end{array}$ & $\begin{array}{c}98 \\
64(65.3) \\
34(34.7)\end{array}$ & 0.11 \\
\hline Tumour size $(\mathrm{cm})$ & $4.33 \pm 3.27$ & $3.30 \pm 3.18$ & 0.01 \\
\hline $\begin{array}{l}\text { Tumour stage } \\
\qquad \begin{array}{l}\text { I } \\
2 \\
3 \\
4\end{array}\end{array}$ & $\begin{array}{l}155 \\
37(23.9) \\
63(40.7) \\
32(20.6) \\
23(14.8)\end{array}$ & $\begin{aligned} & 97 \\
38 & (39.2) \\
34 & (35.0) \\
19 & (19.6) \\
6 & (6.2)\end{aligned}$ & 0.02 \\
\hline $\begin{array}{l}\text { Nodal stage } \\
0 \\
1 \\
2 \\
3\end{array}$ & $\begin{aligned} & 147 \\
43 & (29.2) \\
77 & (52.4) \\
10 & (6.8) \\
17 & (11.6)\end{aligned}$ & $\begin{aligned} & 97 \\
48 & (49.5) \\
33 & (34.0) \\
9 & (9.3) \\
7 & (7.2)\end{aligned}$ & 0.00 \\
\hline $\begin{array}{l}\text { Clinical stage } \\
\text { I } \\
\text { II } \\
\text { III } \\
\text { IV }\end{array}$ & $\begin{array}{l}|6| \\
22(13) \\
61(38) \\
62(39) \\
16(10)\end{array}$ & $\begin{array}{c}100 \\
29(29) \\
40(40) \\
28(28) \\
3(3)\end{array}$ & 0.00 \\
\hline \multicolumn{4}{|l|}{ Treatment } \\
\hline $\begin{array}{l}\text { Pre-surgical therapy } \\
\text { Yes } \\
\text { No }\end{array}$ & $\begin{array}{c}|5| \\
56(37 . \mid) \\
95(62.9)\end{array}$ & $\begin{array}{c}100 \\
24(24) \\
76(76)\end{array}$ & 0.03 \\
\hline $\begin{array}{c}\text { Surgery } \\
\text { Partial mastectomy }\end{array}$ & $\begin{array}{c}|4| \\
53(37.6)\end{array}$ & $\begin{array}{c}100 \\
56(56)\end{array}$ & 0.00 \\
\hline Radical mastectomy & $57(40.4)$ & $19(19)$ & \\
\hline Total mastectomy & $21(14.9)$ & $24(24)$ & \\
\hline Bilateral total mastectomy & $10(7.1)$ & I (I) & \\
\hline Post-surgical therapy & 134 & 71 & \\
\hline Chemotherapy & $36(26.9)$ & $31(43.7)$ & 0.00 \\
\hline Radiation & $35(26.1)$ & $6(8.4)$ & \\
\hline Chemotherapy and radiation & $63(47.0)$ & $34(47.9)$ & \\
\hline $\begin{array}{l}\text { Hormonal therapy } \\
\text { Yes } \\
\text { No }\end{array}$ & $\begin{array}{c}134 \\
70(52.2) \\
64(47.8)\end{array}$ & $\begin{array}{ll}71 \\
41 & (57.7) \\
30 & (42.3)\end{array}$ & 0.00 \\
\hline
\end{tabular}

${ }^{a}$-value $<0.05$ is significant.

women, there were $54(74.0 \%)$ adverse events vs 19 (26.0\%) among old women. Young women with triple-negative tumours had 26 out of $32(81.3 \%)$ adverse events $v s 6$ out of $32(18.7 \%)$ among old women $(P=0.1469)$.

Kaplan-Meier survival curves for DFS in young $v s$ old women was significant $(P=0.032)$ by log-rank test (Figure 3$)$. The DFS differed significantly by molecular subtypes and univariate logrank test $(P=0.0094)$ (Figure 4$)$. The median DFS was 144 months (95\% CI: 84, 144) for luminal B, 60 months (95\% CI: 35, 60) for Lum-Her2 and 63 months (95\% CI: 25, NA) for triple negative. The median DFS was not estimable for luminal A and HER2 due to lack
Table 2 Comparison of biomarker expression and molecular subtypes among young vs old women

\begin{tabular}{|c|c|c|c|}
\hline Variables & $\begin{array}{c}\text { Women } \leqslant \mathbf{4 0} \\
(\%)\end{array}$ & $\begin{array}{c}\text { Women } \geqslant \mathbf{5 0} \\
(\%)\end{array}$ & $P$-value \\
\hline ER status & $n=158$ & $n=99$ & 0.01 \\
\hline Positive & $79(50.0)$ & $65(65.7)$ & \\
\hline Negative & $79(50.0)$ & $34(34.3)$ & \\
\hline Level (\%) & $33.04 \pm 41.67$ & $57.87 \pm 44.65$ & $<0.00$ \\
\hline PR status & $n=158$ & $n=99$ & 0.07 \\
\hline Positive & $60(38.0)$ & $49(49.5)$ & \\
\hline Negative & $98(62.0)$ & $50(50.5)$ & \\
\hline Level (\%) & $18.43 \pm 30.49$ & $27.9 \pm 37.12$ & 0.03 \\
\hline Her2 status & $n=157$ & $n=99$ & 1.00 \\
\hline Positive & $35(22.3)$ & $23(23.2)$ & \\
\hline Negative & $122(77.7)$ & $76(76.8)$ & \\
\hline Amplification level (FISH) & $4.89 \pm 2.66$ & $4.65 \pm 2.91$ & \\
\hline$K 167$ & $n=149$ & $n=98$ & 0.01 \\
\hline High $(>14 \%)$ & $126(82.9)$ & $75(76.5)$ & \\
\hline Low $(\leqslant 14 \%)$ & $23(17.1)$ & $23(23.5)$ & \\
\hline Level (\%) & $49.58 \pm 30.96$ & $40.11 \pm 29.78$ & 0.01 \\
\hline P53 & $n=143$ & $n=98$ & 0.00 \\
\hline Normal (<10\%) & $79(55.2)$ & $72(73.5)$ & \\
\hline High $(\geqslant 10 \%)$ & $64(44.8)$ & $26(26.5)$ & \\
\hline Level (\%) & $31.34 \pm 38.76$ & $17.90 \pm 32.16$ & 0.00 \\
\hline Molecular subtypes & $n=157$ & $n=99$ & 0.05 \\
\hline Luminal $A$ & $18(11.4)$ & $20(20.2)$ & \\
\hline Luminal B & 45 (28.7) & $30(30.3)$ & \\
\hline Her2 subtype & $21(13.4)$ & $8(8.1)$ & \\
\hline Luminal-Her2 & $14(8.9)$ & $15(15.2)$ & \\
\hline Triple negative & $59(37.6)$ & $26(26.2)$ & \\
\hline
\end{tabular}

Abbreviation: $\mathrm{FISH}=$ fluorescent in situ hybridisation.

of DFS events. The difference in survival among the subtypes was significant $(P=0.0092)$ by multivariate Cox proportional hazard model after adjusting for race, age, tumour size, grade and $\mathrm{T}$ and $\mathrm{N}$ stage. Tumour size $(P<0.001), \mathrm{T} \quad(P=0.047)$ and $\mathrm{N}$ stage $(P<0.001)$ were significant predictors of DFS.

\section{DISCUSSION}

In this study, young women with IBCA had significantly higher clinical stage at presentation, larger tumour size, poorly differentiated histology and lower frequency of HR-positive status when compared with their older counterpart, similar to previous studies (Walker et al, 1996; Colleoni et al, 2002; Anders et al, 2009). We have demonstrated the utility of digital image analysis for semiquantification of biomarkers expression applied to routine clinical specimens. The advantage of this technique is the consistency of results with less intra- and inter-observer variability compared with manual estimation (Gokhale et al, 2007; Faratian et al, 2009; Bolton et al, 2010). By semi-quantitative analysis, we have demonstrated for the first time that young women had significantly lower ER and PR levels, higher KI and p53 overexpression compared with older women. On multivariate analyses, tumour size, grade, ER and PR were independently associated with age, but KI was not.

Molecular characterisation of IBCA by gene expression is highly complex and can be performed only in reference laboratories. Routine IHC is simple, economical and several of the biomarkers can be performed simultaneously using the standardised automated techniques. We used IHC as a surrogate tool for gene 
Table 3 Biomarker expression values (\%) according to the molecular subtypes and age groups

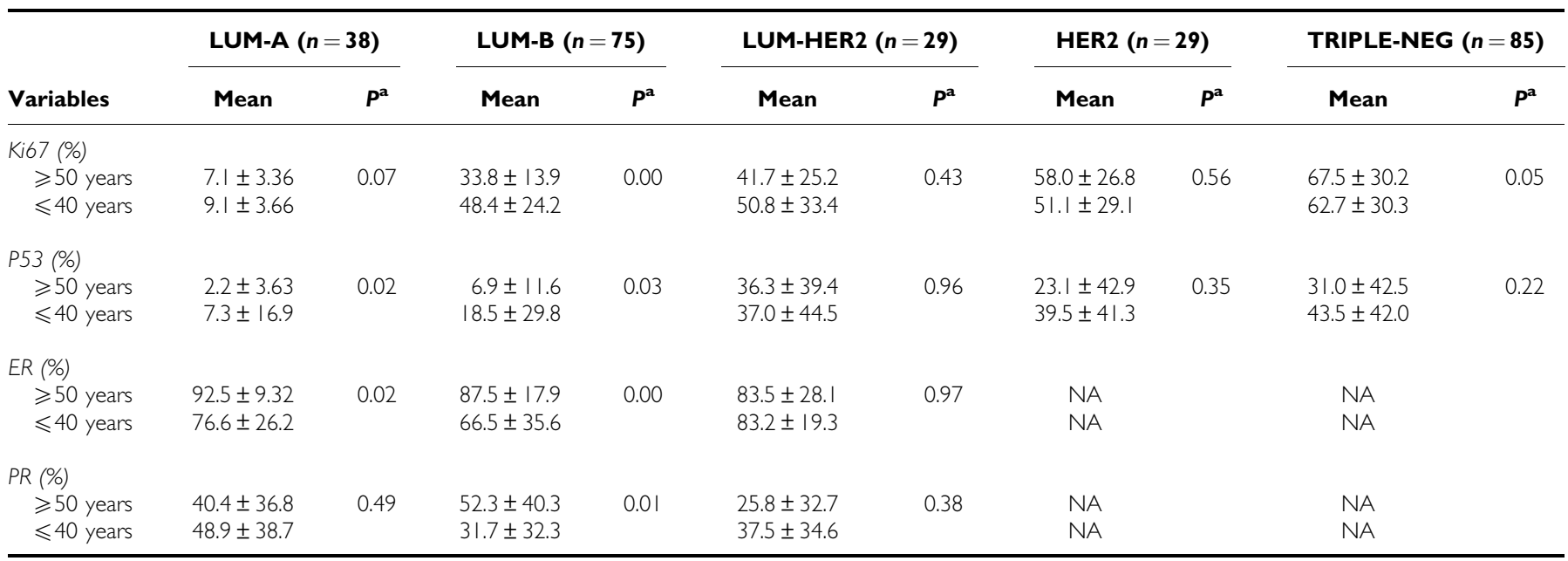

$\mathrm{NA}=$ not applicable. ${ }^{\mathrm{a}} \mathrm{P}$-value of the two-sample $t$-test.

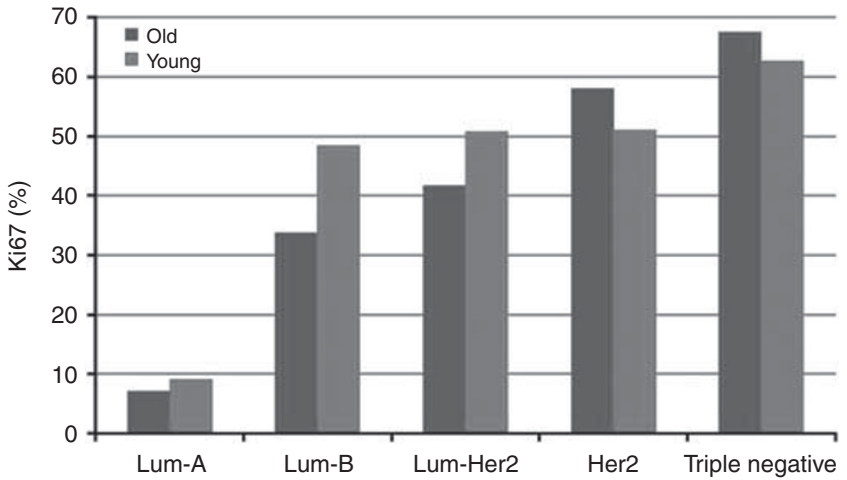

Figure I Relationship between $\mathrm{KI}$ and molecular subtypes of IBCA in young vs old women $(P<0.000 \mathrm{I})$.

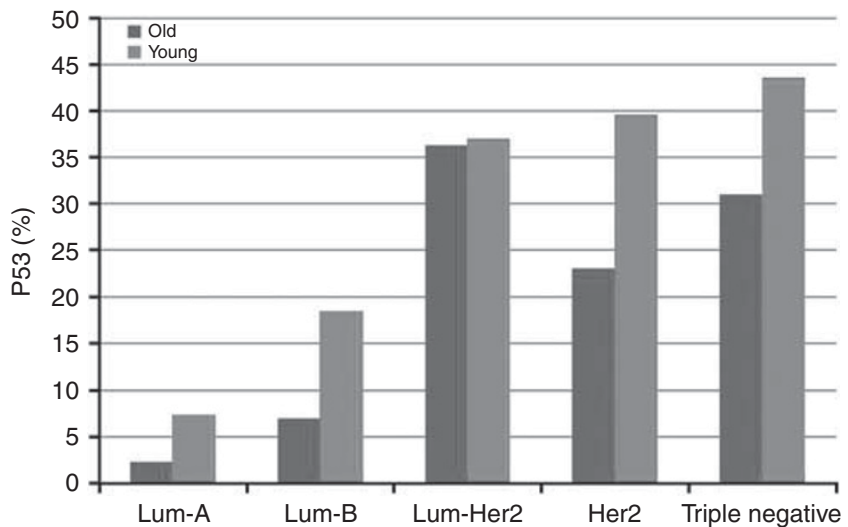

Figure 2 Relationship between p53 expression and molecular subtypes of IBCA in young and old women $(P<0.0001$ and $<0.0003$, respectively).

expression. We observed that molecular subtypes were independently associated with age by multivariate analysis. Triple-negative tumours comprised $38 \%$ among young women vs $26 \%$ in old group. The higher prevalence of triple-negative tumours is most likely due to the predominance of Hispanics and African American women in our population. Triple-negative tumours occur more frequently in young Black and Hispanic women than in young women of other racial groups (Carey et al, 2006; Foulkes et al, 2010). In the Carolina Breast Cancer study, the prevalence of basal

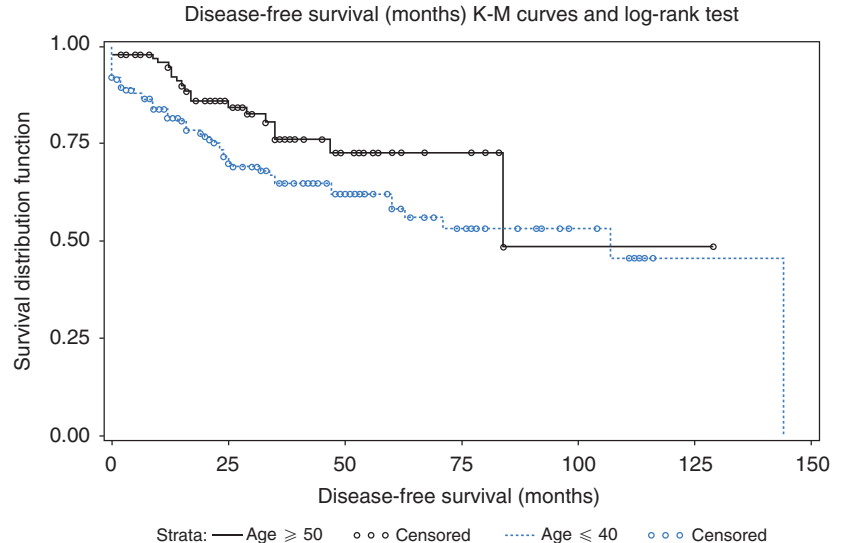

Figure 3 Kaplan-Meier survival curves for DFS in young vs old women $(P=0.032)$ by log-rank test.

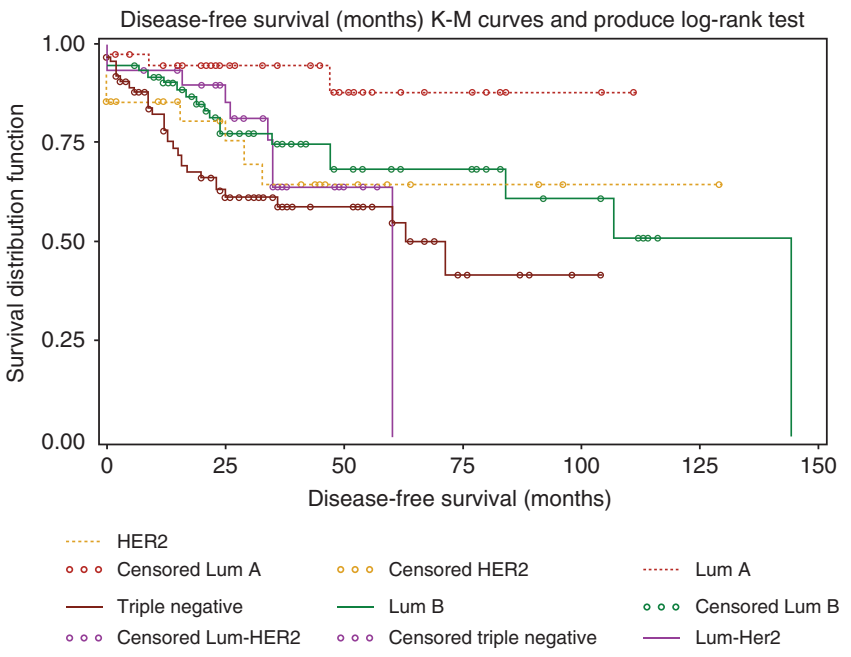

Figure 4 Kaplan-Meier survival curves for DFS in the molecular subtypes of IBCA; univariate log-rank test $(P=0.0094)$ and multivariate Cox proportional hazard model $(P=0.0092)$.

phenotype in premenopausal African American women was 39\% compared with only $16 \%$ in other racial groups (Carey et al, 2006). It has been suggested that the interaction of societal and genetic 
factors may put Black and Hispanic women at increased risk for triple-negative breast cancer (Foulkes et al, 2010). It may be argued that triple negative is not synonymous with basal phenotype. However, the majority of triple-negative tumours express basal phenotypes and both have similar clinical behaviour (Foulkes et al, 2010), although their molecular heterogeneity has been highlighted (Rakha et al, 2009). In our study, triple-negative tumours were poorly differentiated with high KI and p53 and frequently associated with positive lymph nodes compared with other subtypes. Previous observations reported lower incidence of positive lymph node, suggesting that this subtype has a higher propensity to spread by hematogenous route (Fulford et al, 2007; Crabb et al, 2008; Foulkes et al, 2010). Furthermore, triple-negative tumours among young women, when compared with those of older women, were predominantly poorly differentiated with higher frequency of positive lymph nodes. Genetic factors, such as BRCA mutation, have important role in young women with IBCA (Robson et al, 1998; Greenblatt et al, 2001). Triple-negative phenotype, loss of p53 function and high ki67 are the hallmark of BRCA-associated IBCA (Greenblatt et al, 2001). In our study, genetic testing was not consistently performed in all young patients and BRCA mutation was positive in 10 out of the 19 young women that were tested (data not shown).

In our study, luminal B subtype was more prevalent (66\%) than luminal A (34\%). The mean KI for both age groups was $<10 \%$ in luminal $A$ and was $48 \%$ and $34 \%$ among young and old women in luminal B, respectively. Previous studies have shown luminal A to be more common than luminal $\mathrm{B}$, however, proliferation was not evaluated and it is possible that luminal tumours with high proliferation may have been included in the luminal A category (Carey et al, 2006; Ihemeladanu et al, 2007). A very recent study showed luminal $B$ to be more prevalent (77\%) than luminal A (23\%), using proliferation criteria (Cancello et al, 2010). Studies have shown that only $30 \%$ of luminal B tumours overexpress HER2 (Carey et al, 2006; Cheang et al, 2009), therefore in the past, the majority of luminal B tumours were inappropriately classified as luminal A. In our study, HER2 overexpression was seen in $28 \%$ of all the luminal B tumours. Luminal B tumours with HER2 overexpression are distinct from those without HER2 overexpression (Cheang et al, 2009).

The importance of proliferation in luminal tumours has been shown recently. The Oncotype $\mathrm{Dx}$ assay provides prognostic information in patients with HR-positive breast cancer (Paik et al, 2004). The recurrence score is heavily weighted on proliferation besides ER and PR expression (Paik et al, 2004). The MK167 gene that encodes the ki67 protein is highly expressed in luminal B tumours (Perou et al, 1999; Paik et al, 2004; Cheang et al, 2009). The KI in luminal tumours correlated with survival, and the 10year survival for luminal A, B and luminal-her2 was $92 \%, 79 \%$ and $78 \%$, respectively (Cheang et al, 2009). In our study, women with luminal B subtype had inferior survival compared with luminal A. It has been shown that women with luminal B tumours were less responsive to anti-hormonal therapy with significantly higher rates of recurrence and regional relapse compared with women with luminal A tumours (Cheang et al, 2009; Voduc et al, 2010).

An interesting observation not documented previously is that luminal B tumours among young women, when compared with the older group, demonstrated more aggressive features, such as significantly higher histological grade, KI, p53 and significantly lower levels of ER and PR expression. Recently, it was shown that very young women with luminal $B$ breast cancer had worse outcome compared with older women with similar subtype (Cancello et al, 2010) and were more likely to have endocrine unresponsive disease with inferior prognosis compared with older women (Aebi et al, 2000; Colleoni et al, 2002; Ahn et al, 2007; Haffty and Buchholz, 2010). The high proliferation and p53 level, coupled with low ER and PR expression, suggests that these tumours may originate from less-differentiated luminal cells.

There are conflicting reports regarding incidence of Her2 overexpression in young women. Some reported higher incidence in young women (Agrup et al, 2002; Hartley et al, 2006; Anders et al, 2008), whereas others showed no difference in the two age groups (Colleoni et al, 2002; Maru et al, 2005). This reflects the different methodologies and criteria used to determine HER2 status. In this study, the overall rate of HER2 overexpression by FISH assay was similar in the two age groups, although the HER2 subtype was more common among young women.

We have demonstrated for the first time the significant relationship between $\mathrm{KI}$ and $\mathrm{p} 53$ and molecular subtypes of IBCA in both age groups. Differences in proliferation and p53 among the subtypes have been shown by gene expression (Perou et al, 1999; Sorlie et al, 2001). Others have reported only a modest association between proliferation and molecular subtypes using tissue microarray (Bhargava et al, 2009). This may be due to underestimation of proliferation because of sampling error. Assessment of KI by automated analysis on whole-tumour section provides a more accurate estimation of the proliferation index.

We found significant differences in DFS among the subtypes by univariate and multivariate analysis and this was independent of $\mathrm{N}$ and $\mathrm{T}$ stage, tumour size and age, similar to previous other studies (Carey et al, 2006; Sorlie et al, 2001).

This retrospective study has several limitations. Breast cancer in young women has strong genetic influence and risk factors such as family history, parity and genetics were not consistently evaluated in this study.

The classification of IBCA using IHC does not reflect all the molecular subtypes defined by gene expression. However, this study demonstrated that a basic panel of ER, PR, HER2 and ki67 could identify distinct subtypes with different survival outcomes. More importantly, these were performed prospectively by image analysis in a real world fashion and cases were not pre-selected based on tumour size and availability of tissue samples.

\section{CONCLUSION}

We demonstrated significant quantitative differences in biomarker expression relative to age and molecular subtypes. The KI served as a useful parameter for identifying luminal tumours with high proliferation that showed a worse outcome compared with those with low KI. Triple-negative and luminal B subtypes among young women appear to show more aggressive features than those among older women. Molecular subtype defined by IHC was an independent prognostic factor.

\section{REFERENCES}

Aebi S, Gelber S, Castogione-Gertsch M, Gelber RD, Collins J, Thürlimann B, Rudenstam CM, Lindtner J, Crivellari D, Cortes-Funes H, Simoncini E, Werner ID, Coates AS, Goldhirsch A (2000) Is chemotherapy alone adequate for young women with oestrogen receptor positive breast cancer? Lancet 355: 1869-1874
Agrup M, Stal O, Olsen K, Wingren S (2002) C-erb-2 over-expression and survival in early onset breast cancer. Breast Can Res Treat 63: 23-29

Ahn SJ, Son BH, Kim SW, Kim SI, Jeong J, Ko SS, Han W, Korean Breast Cancer Society (2007) Poor outcome of hormone receptor-positive breast cancer at very young age Is due to tamoxifen resistance: nationwide 
survival data in Korea - a report from the Korean Breast Cancer Society. J Clin Oncol 25: 2360-2368

Anders CK, Hsu DS, Broadwater G, Acharya CR, Foekens JA, Zhang Y, Wang Y, Marcom PK, Marks JR, Febbo PG, Nevins JR, Potti A, Blackwell KL (2008) Young age at diagnosis correlates with worse prognosis and defines a subset of breast cancers with shared patterns of gene expression. J Clin Oncol 26: 3324-3330

Anders CK, Johnson R, Litton J, Phillips M, Bleyer A (2009) Breast cancer before age 40 years. Semin Oncol 36: 237-249

Bhargava R, Striebel J, Beriwal S, Flickinger JC, Onisko A, Ahrendt G, Dabbs DJ (2009) Prevalence, morphologic features and proliferation indices of breast carcinoma molecular classes using immunohistochemical surrogate markers. Int J Clin Exp Pathol 2: 444-455

Bolton KL, Garcia-Closas M, Pfeiffer RM, Duggan MA, Howat WJ, Hewitt SM, Yang XR, Cornelison R, Anzick SL, Meltzer P, Davis S, Lenz P, Figueroa JD, Pharoah PD, Sherman ME (2010) Assessment of automated image analysis of breast cancer tissue microarrays for epidemiologic studies. Cancer Epidemiol Biomarkers Prev 19: 992-999

Bonnier P, Romain S, Charpin C, Lejeune C, Tubiana N, Martin PM, Piana L (1995) Age as a prognostic factor in breast cancer: relationship to pathologic and biologic features. Int J Cancer 17: 138-144

Cancello G, Maisonneuve P, Rotmensz N, Viale G, Mastropasqua MG Pruneri G, Veronesi P, Torrisi R, Montagna E, Luini A, Intra M, Gentilini O, Ghisini R, Goldhirsch A, Colleoni M (2010) Prognosis and adjuvant treatment effects in selected breast cancer subtypes of very young women (<35 years) with operable breast cancer. Ann Oncol 21: 1974-1981

Carey L, Perou CM, Livasy CA, Dressler LG, Cowan D, Conway K, Karaca G, Troester MA, Tse CK, Edmiston S, Deming SL, Geradts J, Cheang MC, Nielsen TO, Moorman PG, Earp HS, Millikan RC (2006) Race, breast cancer subtypes and survival in the Carolina Breast Cancer Study. JAMA 295: 2492-2502

Chae BJ, Bae JS, Lee A, Park WC, Seo YJ, Song BJ, Kim JS, Jung SS (2009) p53 as a specific prognostic factor in triple negative breast cancer. Jpn J Clin Oncol 39: 217-224

Cheang MCU, Chia SK, Voduc D, Gao D, Leung S, Snider J, Watson M, Davies S, Bernard PS, Parker JS, Perou CM, Ellis MJ, Nielsen TO (2009) Ki67 index, Her2 status, and prognosis of patients with luminal B breast cancer. I Natl Cancer Inst 101: 736-750

Colleoni M, Rotmensz N, Robertson C, Orlando L, Viale G, Renne G, Luini A, Veronesi P, Intra M, Orecchia R, Catalano G, Galimberti V, Nolé F, Martinelli G, Goldhirsch A (2002) Very young women ( $<35$ years) with operable breast cancer: features of disease at presentation. Ann Oncol 13: 273-279

Crabb SJ, Cheang MC, Leung S, Immonen T, Nielsen TO, Huntsman DD, Bajdik CD, Chia SK (2008) Basal breast cancer molecular subtype predicts for lower incidence of axillary lymph node metastasis in primary breast cancer. Clin Breast Cancer 8: 249-256

Faratian D, Kay C, Robson T, Campbell FM, Grant M, Rea D, Bartlett JM (2009) Automated image analysis for high-throughput quantitative detection of ER and PR expression levels in large scale clinical studies: the TEAM trial experience. Histopathology 55: 587-593

Foulkes WD, Smith IE, Reis-Filho JS (2010) Triple-negative breast cancer. N Engl J Med 363: 1938-1948

Fulford LG, Reiss-Filho JS, Ryder K, Jones C, Gillett CE, Hanby A, Easton D, Lakhani SR (2007) Basal like grade III invasive ductal carcinoma of the breast: patterns of metastasis and long-term survival. Breast Cancer Res 9: R4

Gokhale S, Rosen D, Sneige N, Diaz LK, Resetkova E, Sahin A, Liu J, Albarracin CT (2007) Assessment of two automated imaging systems in evaluation of estrogen receptor status in breast carcinoma. Appl Immunohistochem Mol Morphol 154: 451-455
Greenblatt MS, Chappuis PO, Bond JP, Hamel N, Foulkes WD (2001) TP53 mutations in breast cancer associated with BRCA1 or BRCA2 germ line mutations: distinctive spectrum and structural distribution. Can Res 61: 4092-4097

Haffty BG, Buchholz TA (2010) Molecular predictors of locoregional recurrence in breast cancer: ready for prime time? J Clin Oncol 28(10): 1627-1629

Hartley M, McKinley B, Rogers EA, Kalbaugh CA, Messich HS, Blackhurst DW, Lokey JS, Trocha SD (2006) Differential expression of prognostic factors and effect on survival in young $(<$ or $=40)$ breast cancer patients. A case control study. Am Surg 72: 1189-1194

Ihemelandu CU, Leffall Jr LD, Dewitty RL, Naab TJ, Mezghebe HM, Makambi KH, Adams-Campbell L, Frederick WA (2007) Molecular breast cancer subtypes in premenopausal and postmenopausal African-American women: age-specific prevalence and survival. J Surg Res 143: 109-118

Lin CH, Liau JY, Lu YS, Huang CS, Lee WC, Kuo KT, Shen YC, Kuo SH, Lan C, Liu JM, Kuo WH, Chang KJ, Cheng AL (2009) Molecular subtypes of breast cancer emerging in young women in Taiwan: evidence for more than just westernization as a reason for the disease in Asia. Cancer Epidemiol Biomarkers Prev 18: 1807-1814

Maru D, Middleton LP, Wang S, Valero V, Sahin A (2005) Her2/neu and p53 overexpression as biomarkers of breast carcinoma in women age 30 years and younger. Cancer 103: 900-905

Paik S, Shak S, Tang G, Kim C, Baker J, Cronin M, Baehner FL, Walker MG, Watson D, Park T, Hiller W, Fisher ER, Wickerham DL, Bryant J, Wolmark N (2004) A multigene assay to predict recurrence of tamoxifen treated node negative breast cancer. $N$ Engl J Med 351(27): 2817-2826

Perou CM, Jeffrey SS, van de Rijn M, Rees CA, Eisen MB, Ross DT, Pergamenschikov A, Williams CF, Zhu SX, Lee JC, Lashkari D, Shalon D, Brown PO, Botstein D (1999) Distinctive gene expression patterns in human mammary epithelial cells and breast cancers. Proc Natl Acad Sci USA 96: 9212-9217

Rakha EA, Elshiekh SE, Aleskandaray MA, Habashi HO, Green AR, Powe DG, El-Sayed ME, Benhasouna A, Brunet JS, Akslen LA, Evans AJ, Blamey R, Reis-Filho JS, Foulkes WD, Ellis IO (2009) Triple negative breast cancer. Distinguishing between basal and nonbasal subtypes. Clin Can Res 15: 2302-2310

Robson M, Gilewski T, Haas B, Levin D, Borgen P, Rajan P, Hirschaut Y, Pressman P, Rosen PP, Lesser ML, Norton L, Offit K (1998) BRCAassociated breast cancer in young women. J Clin Oncol 16: 1642-1649

Shavers VL, Harlan LC, Stevens JL (2003) Racial/ethnic variation in clinical presentation, treatment and survival among breast cancer patients under age 35. Cancer 1: 134-147

Sorlie T, Perou CM, Tibshirani R, Aas T, Geisler S, Johnsen H, Hastie T, Eisen MB, van de Rijn M, Jeffrey SS, Thorsen T, Quist H, Matese JC, Brown PO, Botstein D, Lønning PE, Børresen-Dale AL (2001) Gene expression patterns of breast carcinomas distinguish tumor subclasses with clinical implications. Pro Natl Acad Sci USA 98: 10869-10874

Sotriou C, Neo SY, McShane LM, Korn EL, Long PM, Jazaeri A, Martiat P, Fox SB, Harris AL, Liu ET (2003) Breast cancer classification and prognosis based on gene expression profiles from a population-based study. Pro Natl Acad Sci USA 100: 10393-10398

Voduc KD, Cheang MCU, Tydesley S, Gelmon K, Nielsen TO, Kennecke H (2010) Breast cancer subtypes and the risk of local and regional relapse. J Clin Oncol 28: 1684-1691

Walker RA, Lees E, Webb MB, Dearing SJ (1996) Breast carcinomas occurring in young women ( $<35$ years) are different. $\mathrm{Br} J$ Cancer 74 $1796-1800$

Yerushalmi R, Woods R, Ravdin P, Hayes MM, Gelmon KA (2010) Ki 67 in breast cancer: prognostic and predictive potential. Lancet Oncol 11: 174-183

This work is published under the standard license to publish agreement. After 12 months the work will become freely available and the license terms will switch to a Creative Commons Attribution-NonCommercial-Share Alike 3.0 Unported License. 